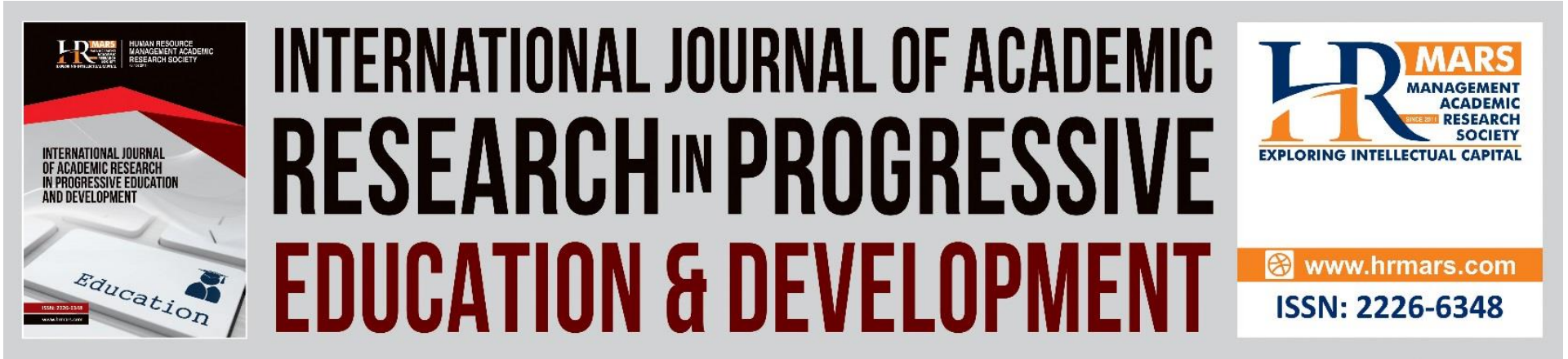

\title{
Religious Education Values for the Urban Poor Children: The Case of the Masa Project
}

\section{Shereeza Mohamed Saniff}

To Link this Article: http://dx.doi.org/10.6007/IJARPED/v10-i3/11544

DOI:10.6007/IJARPED/v10-i3/11544

Received: 24 July 2021, Revised: 29 August 2021, Accepted: 17 September 2021

Published Online: 30 September 2021

\section{In-Text Citation: (Saniff, 2021)}

To Cite this Article: Saniff, S. M. (2021). Religious Education Values for the Urban Poor Children: The Case of the Masa Project. International Journal of Academic Research in Progressive Education and Development, 10(3), 1157-1173.

Copyright: (C) 2021 The Author(s)

Published by Human Resource Management Academic Research Society (www.hrmars.com)

This article is published under the Creative Commons Attribution (CC BY 4.0) license. Anyone may reproduce, distribute, translate and create derivative works of this article (for both commercial and non-commercial purposes), subject to full attribution to the original publication and authors. The full terms of this license may be seen

at: http://creativecommons.org/licences/by/4.0/legalcode

Vol. 10(3) 2021, Pg. 1157 - 1173

Full Terms \& Conditions of access and use can be found at http://hrmars.com/index.php/pages/detail/publication-ethics 


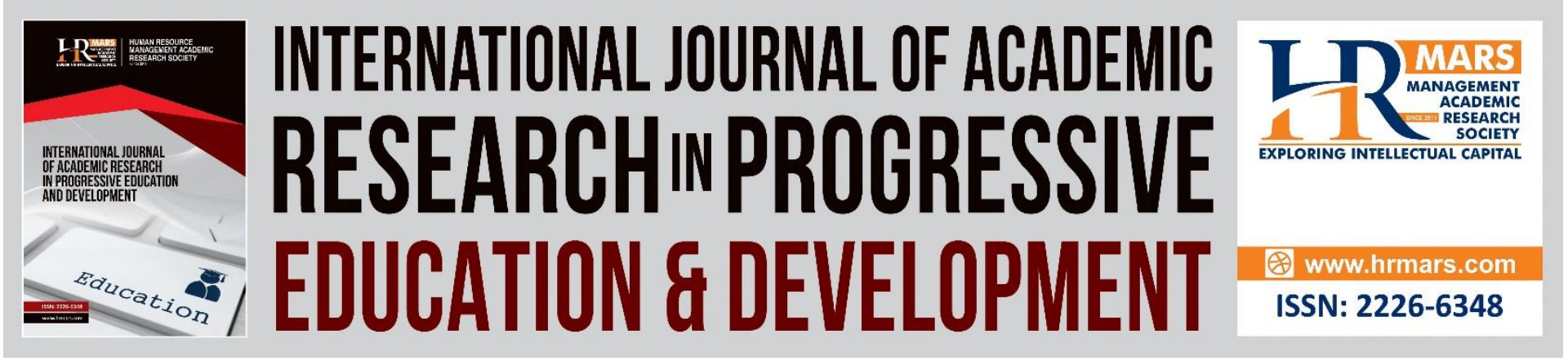

\title{
Religious Education Values for the Urban Poor Children: The Case of the Masa Project
}

\author{
Shereeza Mohamed Saniff \\ Centre for Islamic Development Management Studies (ISDEV) Universiti Sains Malaysia
}

(USM)

Email: shereeza@usm.my

\begin{abstract}
Studies have shown that religion has a significant influence on human behaviour. Thus how one translates one's religious belief to one's daily affairs provide a significant dynamics to the family institution when it comes to managing the relationship of husband-wife and likewise the roles of the husband-father and wife-mother to their children. Thus the influence of religion on the urban poor families cannot be neglected. Our research is based on the religious education values of a group of urban poor families in Pulau Pinang. Through the case study of urban poor families with children aged between seven to 12 years old, situated in one of the mukim in Southwest District in Pulau Pinang, we investigate, through face-to-face interviews and by way of observation, the level of religiosity of the children to that of their parents. We contribute to the theoretical discussion around Islamic religious education by developing a framework linking together religious education values with the urban poor families. Our insights shed light on how in managing urban poverty, strategies that promote family engagement through commitment to religious education values can contribute towards a more efficient way in helping the urban poor families to strive towards poverty alleviation.
\end{abstract}

Keywords: Managing Poverty, Urban Poor, Children, Religious Education, Pulau Pinang

\section{Introduction}

The discussion of the influence of religion on poverty has gone through an interesting evolution form the initial negative nuance to a gradually more positive one. Initially, religion was seen as a form of oppression to the vulnerable groups which ultimately results in the occurrence of prolonged and persistent incidents of poverty. In fact, religion is also seen as a form of restraint that restricts its adherents through rules or dogma (Crabtree, 2010). However, there is a shift in later studies that began to view the relationship positively. Religion is a multifaceted object, incorporating cognitive, emotional, motivational, and behavioural aspect. It is a source of meaning and stability in an uncertain world which contributes to positive health (Hackney \& Sanders, 2003). Religion is now recognised to have significant influence in the process of poverty alleviation and management. Religion is also seen as an important value in the consideration of shaping development strategies and policies. 
The importance of religion in the formation of development strategies and policies generally encompasses the influence or implications of religious values on at least three things. First, religion is relevant to poverty because of its influence on business agencies. Second, religion exerts influence in the formation of political nuances mainly through the formation of subcultures in the social interactions of society. Third, religion influences the multidimensional aspects of poverty in terms of deprivation experienced (OPHI, 2021) in terms of education, educational institutions as well as societal behaviours involving health, lifestyle, healthrelated beliefs and also perceptions of morality (Sedmak, 2019).

These three religious influences stated by Sedmak (2019) are closely related to the three functions of religion towards poverty which consist of the ability of religion to redirect concerns about material poverty to spiritual poverty; the ability of religion to influence morality by encouraging a spirit of generosity, and; religious encouragement to be involved in poverty eradication (Beyers, 2014). Thus religion is recognised to have the abilities to influence individuals facing issues of poverty as a two-pronged method by providing normative guidelines and at the same time serves to motivate. Religion exerts a significant influence on human behaviour (Amin \& Alam, 2008).

This positive influence of religion on poverty indicates the importance of religious education being done optimally to individuals. In this case, exposure should be implemented in the early stages of human life span so that the religious internalization (Ryan et al., 1993) through religious values can be applied to empower individuals from within which can have significant impact on attitudes, behaviours and well-being. Studies indicate that the religiosity and mental health correlation becomes stronger when operationalized in an internal, identified manner (Hackney \& Sanders, 2003). The higher the levels of religiosity the lower the levels of depression, less emotional distress, greater life satisfaction and higher level of positive effect (Cole et al., 2008; Fiala et al., 2002; Pargament et al., 2000; Levin et al., 1995; Ellison et al., 1989).

In referring to religious education, although various models of religious education exist. literature has notably singled out three general models, the monoreligious model, the multireligious model and the interreligious model (Wowor, 2016). This paper is focused on the first model, the monoreligious model. This model aims to internalize the particular religious tradition held by the students and perspectives given are based on the dominant religion. As the families in the research are all Muslims having the Islamic faith, the focus of this paper is on Islam as the dominant religion. Since the inception of Islam, education has been given priority over all other things. Islam is a religion that values education (Yakubu \& Usman, 2021).

Researches have shown how religious involvement affect positively men and women attitudes on family and how they invest their time as husband-father and wife-mother role in the family. This paper sets to examine the level of religiosity of the children to that of their parents. More specifically, the study was conducted on the children of urban poor families in one of the mukim in the Southwest District of Pulau Pinang. These urban families are part of social-academic laboratory project undertaken by the Centre for Islamic Development Management Studies (ISDEV), Universiti Sains Malaysia (USM), with the cooperation of Zakat Pulau Pinang (ZPP) ("the MASA project"). The MASA project spans three years and are divided 
into four phases. The results of this finding is based on the first phase that spanned six months.

The families of the MASA project all adhere to the Islamic code of conduct and abide by the six basic pillars of the Islamic faith as well as the fie pillars of Islam. To discuss this matter further, this paper first highlights the works related to the Islamic perspective on poverty before presenting the findings of empirical studies that have been conducted on the subject of this study. The results of the study also provide recommendations for the formulation of action plans to empower the urban poor households through religious education. The emphasis on their children, as is intended is this paper, provides the needed information to help the MASA project to strategise and plan for the overall MASA Project to provide a holistic framework of human development in which aspects of religiosity is one of the main components identified.

\section{Literature Review}

Although poverty is now recognised to have a multidimensional measurements and approaches, in general, there are two broad categories of economic poverty - the relatively poor category (relative poverty) and very poor category (absolute poverty) (Korayem \& Mashhour, 2014). According to Khan and Ullah (2015), the characteristics of a genuine economy is one that emphasizes on poverty on the one hand and the ability to manage poverty on the other hand. Accordingly, it is found that such characteristics are found in Islam and that Islamic economic system addresses the problem of poverty. This is also supported by Korayem and Mashhour (2014) who stated that the concept of Islamic poverty and the way to overcome it is very different when compared to the concept of secular economy. If the economy is secular, the poor are those who are destitute and are distinguished only from the poor and the very poor. This is different in Islamic economics. In Islam, poverty is divided into two groups, namely the poor and the needy. Although the difference in terminology seems to be from the point of view of terminology only, but when considering the definition of miskin (poor) and fakir (the destitute poor) in Islam, it carries a deeper meaning because this measurement of poor and the destitute poor takes into account values that are intangible such as faith, taqwa (piety), qanaah (feeling of sufficiency), sustenance and blessings. However, due to the definition of poverty brought by the secular economy as a reference example of the definition of "No Poverty" which is the First Goal (Goal 1) in 17 Sustainable Development Goals (UNDP, 2021), then the discussion on the definition of poverty is still in the definition of poverty based on material circumstances of a financial nature.

A different view from this norm however has been put forward by Salleh (2013) on poverty from an Islamic perspective. According to him, there are two categories of poverty according to Islam. First, the poverty faced by a person who is poor in the material aspects as well as his spiritual aspects, his soul, is poor. Second, a person who, although rich in material wealth, is poor in terms of his soul. His views to link poverty with aspects of psychiatry or spirituality is also put forward by other authors such as Grines, Fares and Meguellati (2015). Grine et al. (2015) have studied the relationship of spirituality from an Islamic perspective with a focus on Muslim women entrepreneurs in Malaysia. Their study found that the relationship with Allah SWT acts as the basic denominator to the definition of "spirituality" plays a significant role in determining the priorities of Muslim women entrepreneurs over their functions in 
managing family affairs, carrying out social responsibilities and decision king. More importantly, the study also highlights this spirituality as a motivational driver.

In addition, the relationship of commitment to religion also plays a role in the level of individual life satisfaction. For example, Ellison (1991) states that commitment in the religious aspect refers to the involvement of individuals in community activities involving religious programs. According to him, the effect of participation in social activities enhance social relationships, provide a positive impact on one's mental health and ultimately increase the life satisfaction of the individual. While the study from Schieman et al (2003) added that the aspect of skills and knowledge (mastery) should also be emphasized that religious values in individuals will control their lives, strive to achieve their goals without blaming fate alone. This is one of the skills that can be nurtured as a result of the appreciation of religious values. This is also emphasized by Ellison (1991) in his study who found that the behaviour of individuals directly involved in religious organizations, the frequency of attendance to places of worship and the level of belief in religion will increase their level of quality of life satisfaction.

Research has also shown that most people reporting high levels of religiosity are more likely to feel supported and have higher levels of well-being (Hill \& Pargament, 2003). Religiosity here refers to the quality or extent to which a person is religious (Sim \& Bujang, 2012). A study on employed women found that those who were more religious tended to experience lesser work family conflict (Noor, 1999) and that due the predominantly Malay population in the Malaysian workforce, there is also the need to interpret work according to the religion of Islam (Abdullah, 1994). On a study related to husband-father and wife-mother role of married Malay muslim women, it was found that religion is directly associated with well-being. The religion of Islam, as found in the study, provides a guide on how to live one's life and is associated positively with life satisfaction and negatively with psychological distress (Noor, 2008).

They argued that as the world economy becomes integrated, policy makers must take into considerations of the effects of religion on human behaviour. Furthermore, Malaysia is a country that emphasis very much on religion as the "Rukun Negara" (or Pillars of Malaysia) in which the first pillar is on "Kepercayaan kepada Tuhan" (or the Belief in God). The country is made official to be Muslim country. Other religions are tolerated and the individual's right to the freedom of worship is stated in the country's constitution (The Federal Connstitution, 1957). Abdullah (1996) also stressed that Malaysians are religious. In addition, the government also encouraged all national schools to offer religious classes (Omar \& Dan, 2007). Thus, religion is regarded as very important part of a Malaysian life. It is important therefore to fill the gap in the literature by looking at religiosity as an important variable in the Malaysian context.

More precisely, Beyers (2014) states that religion is able to develop positive values in the individual to enable the eradication of poverty to occur. According to him, this situation occurs because in addition to increasing the motivation to work hard in life, the influence of religious values forms the generous nature of the individual which in turn results in the spirit of helping each other. This function produces two religious functions in managing poverty. First, the formation of guidelines. The formation of guidelines based on these religious values exists from the concept of incentives through reward (reward or paradise). 
Secondly, as motivation through the interpretation of poverty as a form of life's test. Based on such views, Beyers (2014); Sedmak (2019) conclude the function of religion as a two pronged approach in managing poverty towards its eradication.

Based on the concept of poverty and religion, in managing poverty, the poor in material aspects and the poor in the soul as well as the rich in material aspects but poor in spirit should be given priority in managing poverty. These people should be helped earnestly to improve themselves to at least be the poor in wealth but rich in soul, or better yet, to be rich in both wealth and soul (Salleh, 2004). A wealthy soul is associated with good morals and encourage consistency to strive to change the situation of one's life, to always submit and put utmost trust in the Creator to avoid life plagued by poverty which can lead to disbelief (Wahid \& Ahmad, 2010). The inculcation of moral values is in tandem with the philosophy of religious education in Islam. It constitutes a wide range of virtues such as patience, humility, honesty, integrity, tolerance, industry, truthfulness, self-discipline, and others. Such religious education values when effectively imparted can build a society enhanced with spiritual and moral values, and strive to be free from poverty (Yakubu \&Usman, 2021).

\section{Methodology}

The study in this paper analyses the religious values of children from urban poor households residing in one of the mukims in Southwest District, Pulau Pinang and seeks to understand the meaning behind the findings obtained (Creswell, 1994). The data from this study consists of interviews and observation of the children as well as the 15 families (or 26 parents) from urban poor families in a predetermined location. The children aged between seven to 12 years are all part of the project in the study location. This age range was specifically selected as the compulsory school age in Malaysia (Education Act, 1996). This study involves children's participation as an attempt to promote a sense of being who are responsible for their own lives (Curtin, 2001).

The study was conducted amidst the COVID-19 pandemic and throughout the enforcement of the Movement Control Order (MCO) in Malaysia. This is possible as one of the research members live within the community of the predetermined location and has direct access to them. The questions devised were mindful of the children's age and thus were ensured to be of age appropriate and kept to the very minimal. The questions centred primarily on their access to religious education in terms of the type of school attended by the informants, the respondents' involvement in the basic religious education classes (known as KAFA) and assess their understanding on the pillars of the religious, which represent the basic lessons. Each interview session was kept on average between fifteen to thirty minutes. The findings of the interviews were then analysed to examine both the explicit and the implicit providing researchers the opportunity to make evaluations and interpretations of the text or document as well as facial expressions, body language and stressors and intonations used throughout the interview sessions. The analysis is also supported by the researchers' observations on the surrounding environment of the informants to identify access to religious education classes or institutions that exists around the study location.

\section{Findings \& Discussion}

Malaysia is one the most urbanised countries in East Asia and has 19 urban areas with more than 100,000 people (World Bank, 2015). According to O'Neilll (2021), 77.16 percent of 
Malaysia's total population lived in urban areas and cities. Pulau Pinang with a population of between 1 million and 5 million people (DOSM, 2021) is one the urban cities in Malaysia.

The 25 children interviewed in this study were from 15 urban poor families consisting of four single mothers and 11 married couples. There are three other families consisting of single mothers but they do not have children aged seven to 12 years old. The highest level of formal education of the parents to these children were the Sijil Pelajaran Malaysia (SPM) (the loose equivalence of the " $O$ " (Ordinary) Level at the Cambridge General Certificate of Education Examination) whilst two out of 26 parents have a Skills Certificate. From the 11 married couples, eight of the husbands-fathers and one wife-mother of them have health problems or are registered persons with disabilities (OKU) by the Malaysian Welfare Department (JKM) and are issued with an OKU card. They get monthly assistance from JKM ranging from RM220 per month to RM550 per month depending on the severity of their disabilities. All of these 18 families received monthly assistance from ZPP ranging from RM350 to RM500. Out of these 18 urban poor families, one has never attended formal school education whilst the remaining 28 parents were focussed on their work and family after leaving school. All 29 parents stated that they did not have the opportunity to attend any fom of lifelong education (to improve their levels of education or to enlist in training programs to hone talents and skills after leaving school, be-it short term or long term) as a means to improve themselves.

In terms of income, the average income of these families are well below Malaysia's poverty line of RM2,208.00 (Harian, 2020). 14 of them (48.3\%) earn on an average monthly income of between RM100 to RM400, 3 of them (10.3\%) earn an average monthly income of between RM401 to RM800 while 8 of them (27.6\%) earn average monthly income of between RM801 to $\mathrm{RM} 1,200$. The remaining $13.8 \%$ (or 4 ) do not earn an income due to their health conditions (3) or is unemployed (1).

In addition, 15 families (or 26 parents) take advantage of the income opportunities available within a Radius of 5KM from their residence. Only 2 parents work beyond the 5KM radius from their residence because they are still attached to the place of employment before moving to the current residence or are working with relatives in a retail shop. Figure 1 describes the Income Opportunities Utilized by these 15 urban poor families in the MASA project. 


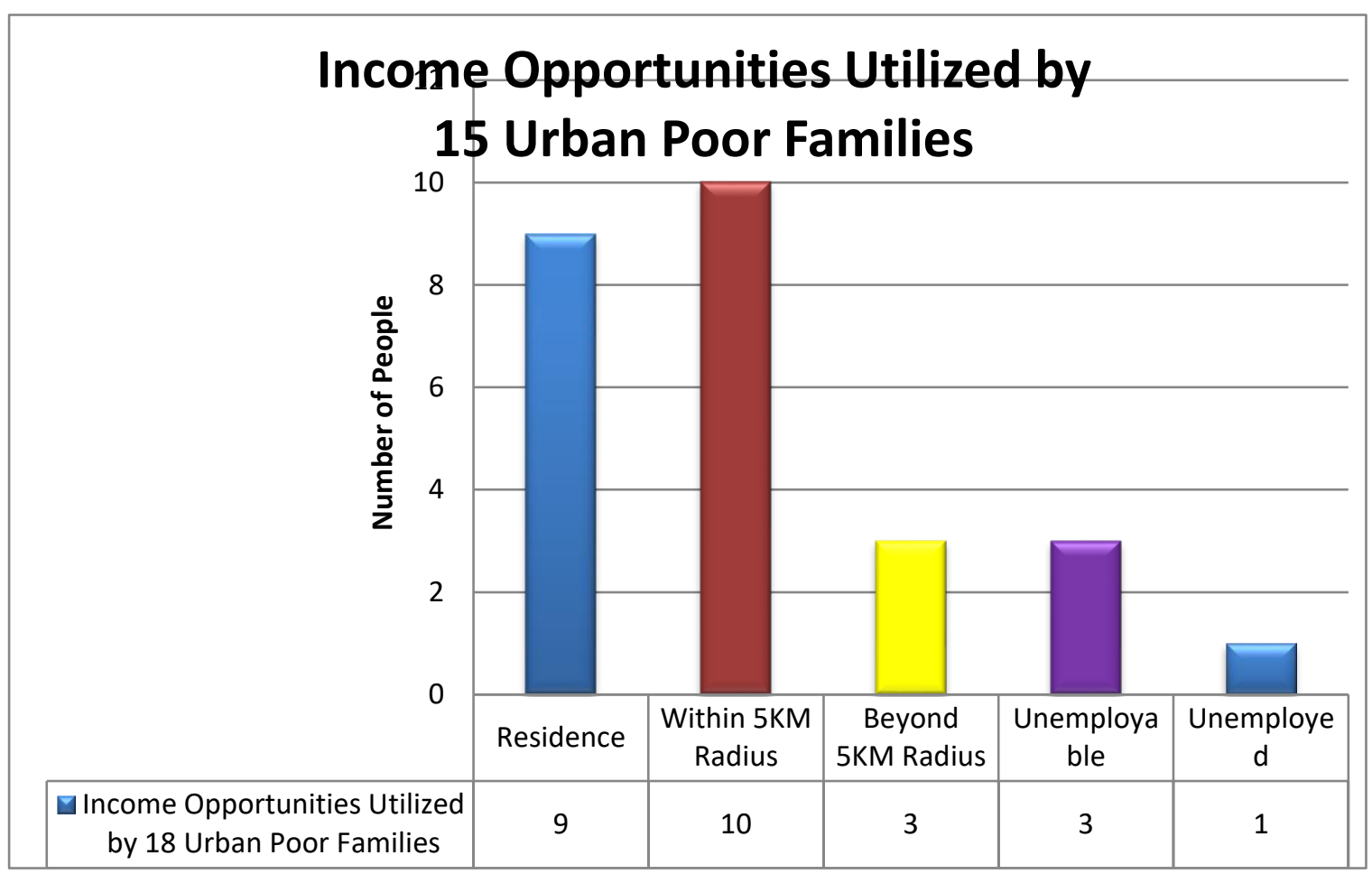

Figure 1: Income Opportunities Utilized of 15 Urban Poor Families

The family dynamics of these 15 families show that one parent is unemployed but his spouse is employed whilst this study was conducted. 19 parents are able to take advantage of the income opportunities available within $5 \mathrm{KM}$ radius of their residence. The three unemployable parents, two of them are husband-father and wife-mother in the family owing to their medical conditions that render them non-productive while one husband-father is bed-ridden due to full-blown stroke of the body.

From the 25 informants of the study, 15 are male and 10 are female. One of the children is attending a Maahad Tahfiz (Full-time Boarding Islamic School) while the majority attended national schools. Of the 24 respondents who attended national schools, the study found that only two of them (siblings) are enrolled in religious education offered by a religious institution nearby. This means, only 3 children obtained specific and structured exposure of formal religious education whether on a full time basis or as an enrichment classes attended on parttime basis to the subject "Pendidikan Islam" (Islamic Education) taught as one of the compulsory subjects in national schools. This shows $88.0 \%$ of these children only obtained religious education values from their respective national schools as shown in Figure 2. 


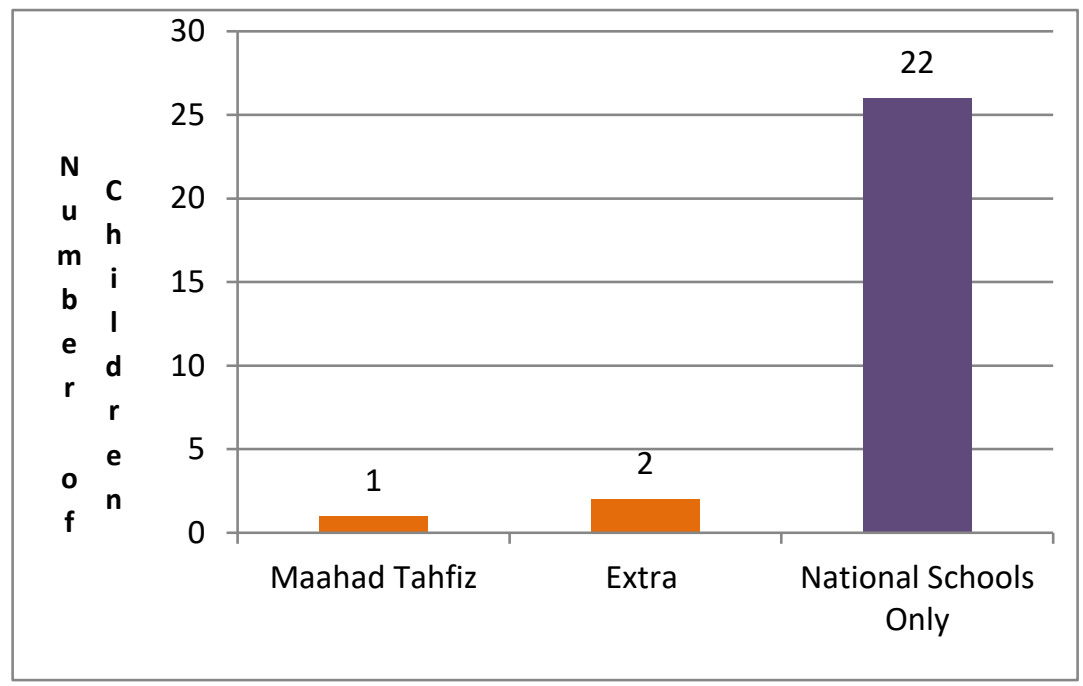

Figure 2: Acquisition of Religious Education

Figure 2 shows the acquisition of religious education for the children. Only a small number of children in the age group of 7 to 12 years, their parents pro-actively sought for religious education beyond the mandatory subject as taught in the national schools. For the child who obtained religious education at Maahad Tahfiz, his religious exposure was obtained full time and continuously throughout the study period because the child lived in the dormitory of Maahad Tahfiz with occasional permission to return to the family. For the other two children who attended the religious education values at a nearby institution, the classes attended were obtained as a supplement to the compulsory education obtained in national schools. Religious education through such classed is attended on a part-time basis either after attending a national school or before attending a national school depending on the national school session.

These findings indicate majority of the children are exposed to a low level of religious education values. Although these children are exposed to religious education values through the subject of Islamic Education as a compulsory subject in national schools, with only an average of thirty-minutes to an hour-a-week session for the subject, the results of the interviews showed that the seven younger ones (aged 7 - 9) were not able to remember well the basics of religious education on the six pillars of articles of Islamic faith and the five basic pillars of Islam let alone understand them. The 18 older ones (aged $10-12$ ) were barely able to remember these basics pillars and were not able to display a deep understanding of what these pillars mean (based on Bloom's taxonomy). In addition to these findings, the children's attitudes towards the compulsory acts of worship (such as the five obligatory prayers especially for those age 10- 12 years old) need serious attention. More time is needed for religious education values for these children.

There are various factors that lead to the occurrence of non-committal to religious education of children for urban poor families. One of these factors is parental encouragement in the family. Cohesive family environment refers to parents who monitor their children's activities, engage their families in regular activities and foster strong parent-child relationship (Manlove et al., 2008). According to Hamid et al. (2011), there is a positive relationship between parents and children in determining the direction and achievement of education in their lives. This 
finding finds support with the study of Shochib (2018) which places the ability of children to know, practice and appreciate the true religious values on the parents. As such, parents play a role in encouraging the achievement of children's religious level through parental support and discussion, communication and inclusive parental involvement in the development of children's education.

As households in urban areas, accessibility to formal religious education as an enrichment class was not an issue. There are two religious schools that provide religious education values to children aged 7 to 12 years within a radius of 1 kilometre from the study location. However, the study discovered that besides the weak cohesive family environment, financial factor is another reason these children are not enrolled in any enrichment religious education values classes such as those offered by KAFA. In a situation of families struggling with the issue of poverty, religious education is seen as a secondary matter in determining the priority of life's necessities. According to Dunn, Dale and Karen (2004), most children who experience dropouts in education come from families experiencing poverty. The background of the children of this study shows two forms of parental income as shown in Figure 3.

\section{Source of Income for 15 Urban Poor Families}

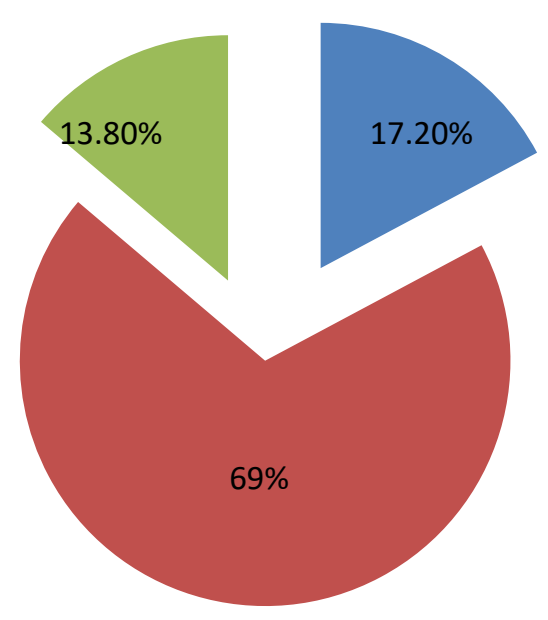

Fixed Income

- Self-Employed/Not Fixed

- Unemployable

Figure 3: Sources of Income for the Parents of the 15 Urban Poor Families

Figure 3 shows the source of income of 15 urban poor families in this study. Three out of the 26 parents (11.5\%), are from five different families, have a fixed income while the source of income for 9 families, 5 of whom are married couples, and are self-employed are varied. This makes up to $73.2 \%$ (or 19) of them are self-employed. They own small-scale home-based businesses while $11.5 \%$ are categorised as non-productive because they have no ability to undertake any occupation or business due to their health conditions while $3.8 \%$ (or 1 ) is unemployed and has no income. 
In contrast to national schools which are provided free of charge (except for certain fees for examination papers and the Parents-Teachers' Association fees which can be waived at the discretion of the school), any religious education outside of the national schools, such as those offered under KAFA classes, requires financial allocation by parents. In a situation where even meeting Malaysia's poverty line at RM2,208 is not possible and getting an average monthly income is a challenge, parents are unable to fulfil the need to ensure that their children receive religious education values beyond those received from the national schools.

These preliminary findings show that, based on the circumstances the families are in, finances are viewed as the main reason that 15 of these urban poor families did not send their children for religious education values such as those offered under KAFA. KAFA is an acronym in Malay that stands for Kelas Asas Fardhu Ain (or loosely translated to mean Indivudual Basic Religious Obligation Classes) which is a state owned religious institutions provided on a part-time basis to parents who opt to send their children for religious education values beyond those given by the national schools. When initial attempts were made to help the children of these families to register and attend KAFA classes, all families agree to enlist their children to KAFA classes. In one sense this finding is consistent with the findings of Abd. Hamid et al (2011) that education is not a burden in life but is an investment to improve the economic status of the family in the future. But the opinion of Abd. Hamid et al (2011) cannot be fully applied in this study. Findings in this study infer that these urban poor parents are much more willing to send their children to national schools not driven by the investment aspect alone but by the incentives given for the poor via the national schools.

In terms of ensuring their children attend national schools, Malaysia has set the policies in place to assist the needy. There are various assistance programmes available to the children through the national schools such as the Free Breakfast Program (PSP) (Harian, 2020), Supplementary Meal Plan (RMT) and Assistance General Schooling (BAP), Monthly Assistance (BB) and Emergency Assistance (BK) under the Poor Students Trust Fund Assistance (KWAPM) (KPM, 2021). In terms of these handouts, apart from schooling assistance received through national schools from the Ministry of Education Malaysia, there is also assistance for early schooling provided by various parties such as zakat institutions in each state, State Assemblymen or Members of Parliament of a certain area, government agencies, nongovernmental-organizations (NGOs) and even the private sectors are involved. Various parties have extended this assistance to help the government develop human capital in the country and ensure that there are no drop-outs experienced by urban or rural poor children.

Based on the above, there are three main factors that drive the determination of parents to ensure that children attend national schools. First, no monthly fees are charged. This is very helpful to parents who are facing poverty. Secondly, there are various forms of assistance received by children in national schools. Third, the support system received by parents from various parties to ensure that there are no drop-outs of children which aims to make it easier for parents to send their children to national schools.

However, these three main factors that attract parents to send their children to national schools, are not present in relations to parents' commitment towards religious education beyond those given by the national schools. The level of parent's commitment towards the need for a more in-depth and robust religious education for their children are not at par with 
sending their children to the national schools. Except for one family, the other 14 families have never been brought to their attention on the need to send their children for religious education outside of the national schools when financial commitment is expected of them. However, when parents were provided the opportunities to be assisted to enrol their children to religious education offered by a religious institution within $1 \mathrm{~km}$ radius of their residence, all 15 families took up the offer. But, when the expected assistance could not materialise, made worse by the COVID-19 pandemic situation, only one out of the 15 families proceeded to enrol their two children for the religious education at the nearby religious institution. Such situation provides two main inferences. First, the financial commitment of parents will increase because no special assistance or special allocation is provided to individuals to follow religious education outside of the national schools. All are done at the discretion of the parents. It is also not mandatory for parents to ensure that their children are sent for religious education as opposed to the national schools (Education Act, 1996). The average dependants for all 18 families (includes the three families with no primary-school going age children) is between four to six people. For the 15 families, the financial commitment needed in providing for religious education in terms of the monthly fees is difficult to bear. Although the nearest religious institution is just within $1 \mathrm{~km}$ radius of their residence, but owing to the busy roads and wide open spaces, safety issues is of utmost concern and parents are not able to give the commitment to send their children to these religious education institutions while enlisting transportation services to and fro those classes are added costs to the families monthly financial commitment. This is the second inference. A cohesive family environment is lacking in these families. For the one family that commits to sending her children for religious education values, all family members were roped-in to help in ensuring their younger siblings attend those religious education values classes on a regular basis indicating the parent's commitment to monitor her children's activities and engage her family members in regular activities as efforts to foster strong parent-child relationships (Manlove et al., 2008). Parents were just not willing to extend their much pressed time and give their commitment in terms of time and effort to see to their children's religious education values. Faced with the high costs of living in the city and pressures of uncertainties aggravated further by the COVID-19 pandemic, ensuring that their children attend religious education outside the national schools with no special assistance makes religious education values as a luxury and not a necessity.

\section{Recommendation}

Following the above discussion, the infusion of strong religious values via religious education provides a more positive effect that encourage religious involvement in the family life. It helps in the shaping of the men and women's role and how they invest their time as husband-father and wife-mother in the family unit. Religion, through effective religious education, play an important role and for the poor people, can help them understand themselves (Schweiger, 2019) cope with their situation and provide the mindset to strive to alleviate themselves from poverty.

There are at least three strategy constructions and intervention programs that can be proposed through this paper. First, strategy building is individual. This paper has presented that the religious education values of urban poor children in national schools through the subject of Islamic Education is insufficient. In the Southwest District of Pulau Pinang alone there are 30 religious institutions under there KAFA flagship (JAIPP, n.d). The findings suggest that in terms of understanding the role of religion in their daily lives, parents of these urban 
poor families know and understand the importance as they readily gave their children's names if assistance is received for their children's enrolment to KAFA classes. This is important because the studies of Ellison (1991); Hairunnizam et al (2010) and McDonald and Gorsuch (2000) have shown the important role of religion in developing one's resilience and competitiveness.

Second, there is a need to help the parents continue their lifelong education on the religion. A high religious knowledge can help a person manage stress and deal with difficult tests in a calm state (Kasberger, 2002). When parents feel and see the importance of religion in shaping and living their daily lives, then children's religious education values will also be seen as something that needs to be emphasized and not as an alternative that can be ignored if lack of money causes parents not to commit to their children's religious education values. This finding is also in line with face-to-face interviews conducted by researchers with a mother in this study who expressed her determination to ensure that her two children attended the nearby KAFA despite being tested in various ways that caused the mother to be under the category of miskin thereby eligible for the monthly zakat assistance. In terms of intervention programs, there is a need for structured religious courses to strengthen parents' knowledge, practice and appreciation of Islam too. The presence and measurement of these aspects of knowledge, practice and deep understanding of the religion needs to be made periodically. In addition, extending the importance of family engagement on religion education needs to be encouraged as well.

Zakat institutions have put systems in place in rendering assistance to help parents prepare for the needs of their children in attending national schools as part of their efforts to contribute towards the preparation of human capital as needed by the country. Zakat officers are entrusted to ensure adequate allocation and such allocations are distributed early so that parents can make the necessary purchases and preparations needed for the national schools. However as the national schools are regarded as the primary pre-disposers towards human capital in the long run, the emphasis is thus rendered more towards the national schools. As opposed to the national schools that have the support of the federal government, the religious aspects, hence the religious institutions of the state is the purview of the state itself. Since the affairs of Islam and the Muslims are under the purview of the state, a systematic and structured assistance or policy can be devised at the state's government level similar (if not at par) to the assistance given to these children at the national schools. Such schemes of assistance act as incentives for parents to commit to ensure their children obtain religious education values beyond those obtained in national schools. The same spirit of assistance in national schools could be devised to ensure that the children of poor families (urban or rural) have access to the religious education values classes as well, but such assistance is not as pronounced as those given via the national schools. Thus, perhaps the various parties who would annually and readily be available to provide early schooling assistance for the national schools, can also extend their assistance to urban poor families with regards to religious education values for their children.

In addition, it is opportune for the state government to provide suitable packages to attract as many urban poor children as possible to attend religious education values offered by the religious institutions throughout the state, especially those classes whose registration has not reached $100 \%$. Networking with NGOs, state governments or other religious institutions as 
well as the private sector to sponsor these children's education at religious institutions such as KAFA can be highlighted. Marketing the courses available in such religious institutions in each of the six Islamic administrative districts in Pulau Pinang as an attraction can be provided either by each religious institution or as a whole by the Islamic Religious Department of Pulau Pinang (Jabatan Agama Islam Pulau Pinang) to provide available information on the existence of religious education values offered at their religious institutions and at the same time as an attraction to emphasize the importance of religious education to children.

\section{Conclusion}

In conclusion, religious education values to children among urban poor families is a phenomenon that will last and will affect the formation of their identities. This issue needs to be taken seriously and requires proactive action to be taken to prevent this from continuing. The implementation of interventions through joint efforts from all parties should be considered so that this phenomenon can be overcome effectively. Religious exposure, especially through education, is important in the process of poverty eradication so that the poverty that can be eradicated is not only material poverty but also spiritual poverty. The long-term implications of this result are expected to give birth to a generation of Muslims who not only develop the economy but at the same time develop their personality and personality. Religious education that is a long-term investment should be the focus of efforts to develop self-improvement apart from the support and encouragement from parents. Success in educating the soul of the child especially the religious aspect will increase the level of understanding and even it will eventually increase awareness and change the attitude slowly to be more towards a positive attitude.

\section{Acknowledgement}

Special thanks to Zakat Pulau Pinang (ZPP) and the Centre for Islamic Development Management (ISDEV), Universiti Sains Malaysia (USM) for making it possible for this paper to be written. This paper is part of the research entitled Socio-Academic Laboratory in the Southwest District of Pulau Pinang Project (The MASA Project).

The author wish to also thank Ahmad Shaifful Anuar Ahmad Shukor, PhD, Liaison Officer, (Pegawai Seranta) of the MASA project for rendering assistance in the collection of data for this paper.

\section{Corresponding Author}

Shereeza Mohamed Saniff

Centre for Islamic Development Management Studies (ISDEV), Universiti Sains Malaysia, 11800 USM, Pulau Pinang

Email: shereeza@usm.my

\section{References}

Hamid, A. Z., Othman, J., Ahmad, A., \& Ismail, I. (2011). Hubungan Antara Penglibatan Ibu Bapa dan Pencapaian Akademik Pelajar Miskin di Negeri Selangor. Journal of Islamic and Arabic Education, 3(2), 31-40.

Abdullah, A. (1994). Leading the Motivating the Malaysian Workforce. Malaysian Management Review, 29(3), 82-101. 
Abdullah, A. (1996). Going Glocal: Cultural Dimensions in Malaysian Management. Kuala Lumpur: Malaysian Institute of Management.

Amin, S., \& Alam, I. (2008). Women's Employment Decisions in Malaysia: Does Religion Matter? Journal of Socio-Economics, 37, 2368-2379. http://dx.doi.org/10.1016/j.socec.2008.04.012

Harian, B. (2020). Garis Kemiskinan Bukan Ukuran Gaji Minimum - Bank Dunia. Retrieved from https://www.bharian.com.my/bisnes/lain-lain/2020/07/711914/garis-kemiskinanbukan-ukuran-gaji-minimum-bank-dunia.

Beyers, J. (2014). The Effect of Religion on Poverty. HTS Teologiese Studies/Theological Studies, 70(1), 1-8.

Civera, C., Colle, D. S., \& Casalegno, C. (2019). Stakeholder Engagement through Empowerment: The Case of Coffee Farmers. Business Ethics: A Eur Rev. 28, 156- 174. https://doi.org/10.1111/beer.12208.

Cole, B. S., Hopkins, C. M., Tisak, J., Steel, J. L., \& Carr, B. I. (2008). Assessing Spiritual Growth and Spiritual Decline following a Diagnosis of Cancer: Reliability and Validity of the Spiritual Transformation Scale. Psycho-oncology, 17(2), 112-121. http://dx.doi.org/10.1002/pon.1207.

Crabtree, S. (2010). Religiosity Highest in World's Poorest Nations: United States is among the rich countries that buck the trend, Gallup, World, 31 August 2010. Accessed from https://news.gallup.com/poll/142727/Religiosity-Highest-World-PoorestNations.aspx.

Creswell, J. W. (1994). Research design: Qualitative and quantitative approaches. London: Sage Publication.

Curtin, C. (2001). Eliciting Children's Voices in Qualitative Research. American Journal of Occupational Therapy, 55, 295-302, https://doi.org/10.5014/ajot.55.3.295.

Dunn, C., Dale, C., \& Karen, R. (2004). Variables affecting students' decision to drop out of school. Remedial and Special Education, 314-323.

Ellison, C. (1991). Religious Involvement and Subjective Well-Being. Journal of Health and Social Behaviour. 32, 80-99.

Ellison, C. G., Gay, D. A., \& Glass, T. A. (1989). Does religious commitment contribute to individual life satisfaction? Social Forces, 68, 100-123.

Fiala, W. E., Bjorck, J. P., \& Gorsuch, R. (2002). The Religious Support Scale: Construction, validation, and cross validation. American Journal of Community Psychology, 30, 761786. http://dx.doi.org/10.1023/A:1020264718397.

Federal Constitution, 1957. (2009). Ninth Schedule. List II - State List. Retrieved from https://www.jac.gov.my/spk/images/stories/10_akta/perlembagaan_persekutuan/fed eral_constitution.pdf.

Grines, F., Fares, D., \& Meguellati, A. (2015). Islamic spirituality and entrepreneurship: A case study of women entrepreneurs in Malaysia. The Journal of Happiness \& Well-Being, 3(1), 41-56.

Hackney, C. H., \& Sanders, G. S. (2003). Religiosity and Mental Health: A Meta-Analysis of Recent Studies. Journal for the Scientific Study of Religion 42(1), 43-55.

Kasberger, E. R. (2002). A Correlational Study of Post-Divorce Adjustment and Religious Coping Strategies in Young Adults of Divorced Families. Second Annual Undergraduate Research Symposium CHARIS Institute of Wisconsin Lutheran College. Milwaukee. Accessed from http://citeseerx.ist.psu.edu/viewdoc/download? doi=10.1.1.424.7706\&rep= rep1\&type=pdf. 
Kementerian Pendidikan Malaysia (KPM). (2021). Bantuan Kumpulan Wang Amanah Pelajar Miskin (KWAPM). Accessed from https://www.moe.gov.my/en/ bantuan-pembelajaranmenu/bantuan-kumpulan-wang-amanah-pelajar-miskin-kwapm.

Kementerian Pendidikan Malaysia (KPM). (2021). Rancangan Makanan Tambahan (RMT). Accessed from https://www.moe.gov.my/en/bantuan-pembelajaran-menu/rancanganmakanan-tambahan-rmt-2.

Khan, Z., \& Ullah, K. (2015). Conceptualizing poverty in capitalism and Islam. Al-Idah, 31, 2636.

Korayem, K., \& Mashhour, N. (2014). Poverty in secular and Islamic economics; Conseptualization and poverty alleviation policy, with refrence to Egypt. Topic in Middle Eastern and African Economies, 16(1), 1-16.

KPM (Kementerian Pendidikan Malaysia). (2003). Dasar Pengoperasian Pendidikan Rendah Wajib. https://www.moe.gov.my/en/primary-school/dasar-pengoperasianpendidikan-rendah-wajib.

Laal, M. (2012). Benefits of Lifelong Learning, Procedia - Social and Behavioral Sciences, 46, 4268-4272, https://doi.org/10.1016/j.sbspro.2012.06.239.

Levin, J. S., Chatters, L. M., \& Taylor, R. J. (1995). Religious effects on health status and life satisfaction among Black Americans. Journal of Gerontology (Social Sciences), 50B, S154S163. http://dx.doi.org/10.1093/geronb/50B.3.S154.

Majlis Agama Islam Wilayah Persekutuan (MAIWP). (2014). Bagaimana Wang Zakat Diagihkan. Accessed from file:///C:/Users/User/Downloads/Agihan-Zakat -MAIWP-2014.pdf.

Manlove, J., Logan, C., Moore, K. A., \& Ikramullah, E. (2008). Pathways from Family Religiosity to Adolescent Sexual Activity and Contraceptive Use. Perspectives on Sexual and Reproductive Health, 40(2):105-117, doi: 10.1363/4010508.

Salleh, M. S. (2004). Menangani Kemiskinan Secara Islam. Dlm. Mohamad Khairudin Mohamad \& Ahmad Syahir Sarani (Ed.), Pembasmian Kemiskinan Bandar dan Luar Bandar. Petaling Jaya, Selangor Darul Ehsan: Institut Perkembangan Minda (INMIND), 51-105.

Salleh, M. S. (2015). Concepts in Islamic Economics Revisited: The Case of Poverty. In Taha Egri \& Necmettin Kizilkaya (Eds.), Islamic Economics - Basic Concepts, New Thinking and Future Directions. United Kingdom: Cambridge Scholars Publishers, 181-199.

Noor, M. N. (1999). Roles and Women's Well-being: Some Preliminary Findings from Malaysia. Sex Roles, 41(314), 123-145. http://dx.doi.org/10.1023/A:1018846010541

Noor, M. N. (2008). Work and Women's Well-being: Religion and Age as Moderators. Journal of Religion and Health, 47, 476-490. http://dx.doi.org/10.1007/s10943-008-9188-8.

Omar, N., \& Dan, C. (2007). Race, gender and religion within the construct of 'Bangsa Malaysia' and 'National Islamic Identity' in Malaysian literature. Journal of English Studies and Comparative Literature, 9(1), 44-54.

Neilll, A. (2021). Urbanization in Malaysia 2020. Retrieved from https://www.statista.com/statistics/455880/urbanization-in-malaysia/.

Oxford Poverty and Human Development Initiative (OPHI)(2021). Policy - A Multidimensional Approach. Retrieved from https://ophi.org.uk/policy/multidimensional-poverty-index/.

Pargament, K., Koenig, H., \& Perez, L. (2000). The many methods of religious coping: Development and initial validation of the RCOPE. Journal of Clinical Psychology, 56, 519543. http://dx.doi.org/10.1002/(SICI)1097-4679(200004)56:43.0.CO;2-1. 
Wowor, J. P. (2016) The Role of Religious Education in Promoting Religious Freedom: A Mutual Enrichment Between "My Story," "Your Story," and "Our Stories", The Review of Faith \& International Affairs, 14(4), 98-106. DOI: 10.1080/15570274.2016.1248527.

Ryan, R. M., Rigby, S., \& King, K. (1993). Two Types of Religious Internalization and Their Relations to Religious Orientation and Mental Health. Journal of Personality and Social Psychology 65, 586-596.

Schieman, S., Nguyen, K., \& Elliott, D. (2003). Religiosity, Socioeconomic Status, and the Sense of Mastery. Social Psychology Quarterly, 66(3), 202-221.

Said, N. A., \& Khairuldin. (2017). Freedom of Speech in Islam and its Connection with Street Demonstrations. International Journal of Academic Research in Business and Social Sciences, 7(4), 122-129.

Khairuldin, Embong, A. H., Anas, W. N. I. W. N., Ismail, D., Ibrahim, I., \& Fauzi, N. (2017). Freedom of Speech: A Comparative Study between Islam and Malaysian Laws. International Journal of Academic Research in Business and Social Sciences, 7(2), 22226990.

Ibrahim, I., \& Khairuldin. (2017). Fatwa as a Medium Da'wah: Studies on the Role of Mufti as a Preacher. International Journal of Academic Research in Business and Social Sciences, 7(4), 10-18.

Schweiger, G. (2019). Religion and Poverty. Palgrave Communications, 5, 97. Retrieved from https://www.nature.com/articles/s41599-019-0294-x.

Sedmak, C. (2019). Evidence-based dialogue: The relationship between religion and poverty through the lens of randomized controlled trials. Palgrave Communications, 5(8), 1-7.

Shochib, M. (2018). Pola Suh Orang Tua Dalam Membentuk Anak Mengembangkan Disiplin Diri, Jakarta: Rineka Cipta.

Sim, A. K. S., \& Bujang, S. (2012). Work-Family Interface of Hospitality Industry in Malaysia: The Moderating Effects of Religiosity. Asian Social Science, 8(8). URL: http://dx.doi.org/10.5539/ass.v8n8p139.

Harian, S. (2020). Perluas kumpulan sasaran program makanan sekolah oleh Jarud Rimadan Khalidi. Accessed from https://www.sinarharian.com.my/article /73022/KHAS/Pendapat/Perluas-kumpulan-sasaran-program-makanan-sekolah.

The World Bank. (2015). Malaysia Among the Most Urbanized Countries in East Asia. Retrieved from https://www.worldbank.org/en/news/feature/2015/01/26/malaysiaamong-most-urbanized-countries-in-east-asia.

United Nations Development Programme (UNDP). (2021). Goal 1: No Poverty. https://www.undp.org/content/undp/en/home/sustainable-development-goals/goal1-no-poverty.html.

Wahid, H., \& Ahmad, S. (2010). Pengaruh faktor keagamaan terhadap kualiti hidup individu: Kajian kes asnaf fakir dan miskin. Paper Work Seminar Kebangsaan MACFEA ke-14 at 13-14 Julai 2010 di Bangi Selangor.

McDonald, W. A., \& Gorsuch, R. L. (2000). Surrender to God: An additional coping style? Journal of Psychology and Theology, 28, 149-161.

Yakubu, A., \& Usman, D. (2019). Islamic Education Values: A Panacea for Poverty Allevation in Nigeria. European Journal of Social Sciences Studies, 4(2), 52-57.

Zakat Pulau Pinang (ZPP). (2020). Jenis Agihan. Accessed from https://www.zakatpenang. com/zpp/index.php/agihan/jenis-agihan. 